\title{
Cinegeo
}

International Journal of Environment and Geoinformatics (IJEGEO) is an international, multidisciplinary, peer reviewed, open access journal.

\section{Effect of seasonal changes on steroid hormones concentrations in the Golden Horn Estuary (Sea of Marmara, Turkey)}

\section{Nagihan E. KORKMAZ, Nuray CAGLAR (BALKIS), Abdullah AKSU, Tuba UNSAL}

\author{
Chief in Editor \\ Prof. Dr. Cem Gazioğlu \\ Co-Editors \\ Prof. Dr. Dursun Zafer Şeker, Prof. Dr. Şinasi Kaya, \\ Prof. Dr. Ayşegül Tanık and Assist. Prof. Dr. Volkan Demir
}

Editorial Committee (August 2020)

\begin{abstract}
Assos. Prof. Dr. Abdullah Aksu (TR), Assit. Prof. Dr. Uğur Algancı (TR), Prof. Dr. Bedri Alpar (TR), Prof. Dr. Lale Balas (TR), Prof. Dr. Levent Bat (TR), Prof. Dr. Paul Bates (UK), İrşad Bayırhan (TR), Prof. Dr. Bülent Bayram (TR), Prof. Dr. Luis M. Botana (ES), Assos. Prof. Dr. Gürcan Büyüksalih (TR), Prof. Dr. Nuray Çağlar (TR), Prof. Dr. Sukanta Dash (IN), Dr. Soofia T. Elias (UK), Prof. Dr. A. Evren Erginal (TR), Assoc. Prof. Dr. Cüneyt Erenoğlu (TR), Dr. Dieter Fritsch (DE), Prof. Dr. Çiğdem Göksel (TR), Prof.Dr. Lena Halounova (CZ), Prof. Dr. Manik Kalubarme (IN), Dr. Hakan Kaya (TR), Assist. Prof. Dr. Serkan Kükrer (TR), Assoc. Prof. Dr. Maged Marghany (MY), Prof. Dr. Michael Meadows (ZA), Prof. Dr. Nebiye Musaoğlu (TR), Prof. Dr. Masafumi Nakagawa (JP), Prof. Dr. Hasan Özdemir (TR), Prof. Dr. Chryssy Potsiou (GR), Prof. Dr. Erol Sarı (TR), Prof. Dr. Maria Paradiso (IT), Prof. Dr. Petros Patias (GR), Prof. Dr. Elif Sertel (TR), Prof. Dr. Nüket Sivri (TR), Prof. Dr. Füsun Balık Şanlı (TR), Prof. Dr. Uğur Şanlı (TR), Duygu Ülker (TR), Prof. Dr. Seyfettin Taş (TR), Assoc. Prof. Dr. Ömer Suat Taşkın (US), Dr. İnese Varna (LV), Dr. Petra Visser (NL), Prof. Dr. Selma Ünlü (TR), Assoc. Prof. Dr. İ. Noyan Y1lmaz (AU), Prof. Dr. Murat Yakar (TR), Assit. Prof. Dr. Sibel Zeki (TR)
\end{abstract}

Abstracting and Indexing: TR DIZIN, DOAJ, Index Copernicus, OAJI, Scientific Indexing Services, International Scientific Indexing, Journal Factor, Google Scholar, Ulrich's Periodicals Directory, WorldCat, DRJ, ResearchBib, SOBIAD 
Research Article

\title{
Effect of seasonal changes on steroid hormones concentrations in the Golden Horn Estuary (Sea of Marmara, Turkey)
}

\author{
Nagihan E. Korkmaz* iD, Nuray Caglar (Balkis) iD, Abdullah Aksu iD, Tuba Unsal \\ Istanbul University, Institute of Marine Science and Management, Department, of Chemical Oceanography, 34134 Vefa Istanbul, TR
}

* Corresponding author: Nagihan E. Korkmaz

Received 09 April 2020

E-mail: nagihan.ersoy@istanbul.edu.tr Accepted 01 May 2020

How to cite: Korkmaz et al., (2020). Effect of seasonal changes on steroid hormones concentrations in the Golden Horn Estuary (Marmara Sea, Turkey), International Journal of Environment and Geoinformatics (IJEGEO), 7(1): 157-164. DOI: 10.30897/ijegeo.717418

\begin{abstract}
In this study, the presence, distribution and concentration of steroidal hormones (Estrone, $17 \beta$-estradiol and $17 \alpha$-ethynylestradiol) were examined in the Golden Horn Estuary (Sea, of Marmara, Turkey) for one year. The bottom and surface water samples were collected seasonally from nine stations in the Golden Horn Estuary. In order to determine the hormone levels, solid phase extraction was applied to the water samples and then these samples were analyzed by HPLC with DAD detector. Recoveries of these hormones ranged from $92-100 \%$ for estuary water.
\end{abstract}

The highest concentrations of estrone, $17 \beta$ - estradiol, $17 \alpha$ - ethynylestradiol were measured as $1.069 \mu \mathrm{g} / \mathrm{L}, 5.25 \mu \mathrm{g} / \mathrm{L}, 1.65 \mu \mathrm{g} / \mathrm{L}$ in Golden Horn, respectively. The concentrations of these three hormones are found higher in bottom water than the surface water and the highest concentrations of all hormones were determined in winter season.

Keywords: Endocrine disrupting compounds, steroid hormones, estuary, seasonal variation

\section{Introduction}

Emerging contaminants (ECs) that consist of pharmaceuticals, endocrine-disrupting chemicals (EDCs), industrial chemicals, surfactants, personal care products (PPCPs) are a major concern in many countries (Sarkar et al. 2019). Pharmaceuticals, hormones and PPCPs have been using continuously all around the world. A wide variety of product options and increasing human population have boosted the release of these contaminants into the environment.<smiles>C[C@]12CC[C@@H]3c4ccc(O)cc4CC[C@H]3[C@H]1CCC2=O</smiles>

Estrone

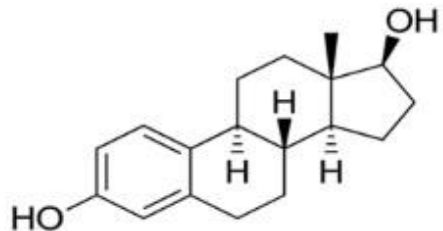

$17 \beta$ - estradiol
Estrogens are known as steroid hormone-chemicals that are responsible for the growth and reproduction system of humans and animals. These hormones are also found in plants and fungi (Hook, 1997). Steroid estrogens can be grouped as synthetic or natural hormones (Fig. 1, Table 1). 17 $\beta$-estradiol and estrone are natural hormones are secreted by women. $17 \alpha$ - ethynylestradiol is a synthetic compound that is widely used in contraceptive pills and animal feed (Gimiliani et al. 2016).

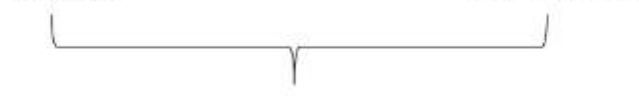

Natural compounds

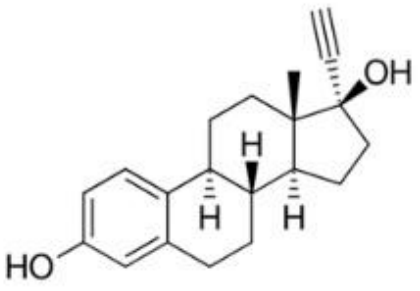

17 $\alpha$ - ethinylestradiol

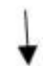

Synthetic compound

Fig. 1. Chemical structure of steroidal compounds.

Estrogen hormones have a low biodegradability. The solubility of natural estrogens in aquatic environments is approximately $3 \mathrm{mg} / \mathrm{L}$ and that of synthetic estrogen is $0.3 \mathrm{mg} / \mathrm{L}$ (Roshan and Taghizadeh, 2019). However, some researchers are reported that solubility can be $\mathrm{pH}-$ dependent. At $\mathrm{pH}$ 10, relative solubilities of estrogens are found higher (Adeel et al. 2017).

Estrogens are commonly found in water supplies such as groundwater, drinking water, surface water and 
municipal wastewater also in soil and refined sewage effluents (Mulroy, 2001; Ternes, 2001; Adeel et al. 2017).

Table 1. Physicochemical properties of steroidal compounds (Aydın and Talinli, 2013; Puckowski et al. 2016).

$\begin{array}{ccccc}\text { Compounds } & \begin{array}{c}\text { Molecular } \\ \text { Formula }\end{array} & \begin{array}{c}\text { Molecular } \\ \left(\mathbf{g ~ m o l}^{-1}\right)\end{array} & \mathbf{p K}_{\mathbf{a}} & \begin{array}{c}\mathbf{L o g} \\ \mathbf{K}_{\text {ow }}\end{array} \\ \begin{array}{c}\text { Estrone } \\ 17 \beta \text {-estradiol }\end{array} & \mathrm{C}_{18} \mathrm{H}_{22} \mathrm{O}_{2} & 270.37 & 10.5 & 3.13 \\ 17 \alpha- & \mathrm{C}_{18} \mathrm{H}_{24} \mathrm{O}_{2} & 272.39 & 10.6 & 4.01 \\ \mathrm{C}_{20} \mathrm{H}_{22} \mathrm{O}_{2} & 296.40 & 10.4 & 3.67\end{array}$

ethynylestradiol

These hormones can enter into the water via domestic wastes, industrial and agricultural activities (Fig.2). This case can lead to public health risks. Especially, the natural estrogens in animal and human waste cause a major threat to the environment. Also, the application of animal manure being an alternative nutrient source for organic farming are increased these risks (Xuan et al. 2008).

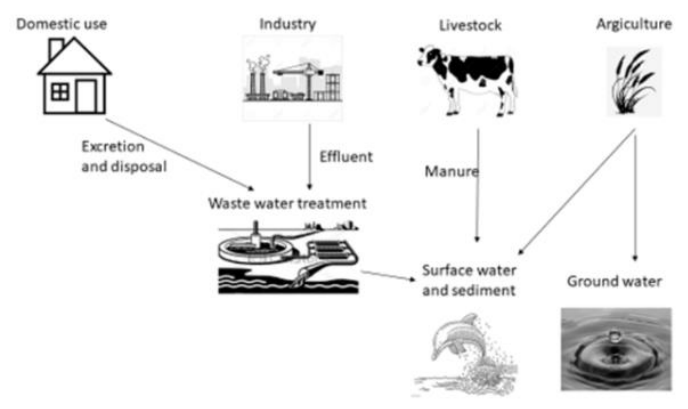

Fig. 2. Sources and pathways of steroidal hormones in the environment

Many studies are performed about the presence of hormones in aquatic environments (Pal et al. 2010, Kolodziej and Sedlak 2007). Although new developments in technology allow detecting even small amounts of these contaminants, the studies that performed so far are not enough to elucidate this environmental problem. The aim of this study to detect the presence, distribution and concentration of steroidal hormones (estrone, 17 $\beta$-estradiol and $17 \alpha-$ ethynylestradiol) in the Golden Horn Estuary. So far, there have not been any studies showing the presence and concentration of these hormones in the Golden Horn Estuary (Sea of Marmara, Turkey). Therefore, this study provides valuable information for future environmental and human health risk assessment studies.

\section{Materials and Methods}

\section{Chemicals, standards and reagents}

All of the compounds were of high purity grade $(>95 \%$ or higher). Steroid hormones; estrone, $17 \beta$-estradiol and $17 \alpha$ - ethynylestradiol were purchased from SigmaAldrich (Steinheim, Germany). The physicochemical properties of these hormones (molecular formula and weight, pKa and log Kow) are given in Table 1. Stock solutions were prepared in acetonitrile and stored at $20^{\circ} \mathrm{C}$. Methanol and acetonitrile were of HPLC grade and acquire from Merck (Germany). Potassium dihydrogen phosphate was of analytical grade and supplied by Fluka (USA). Solid-phase extraction (SPE) cartridges, packed with $500 \mathrm{mg} / 6 \mathrm{~mL}$ of Cleanert PEP, were purchased from Agela Technologies (Torrance, USA).

\section{Sample collection}

The water samples were collected seasonally from nine stations in the Golden Horn Estuary throughout the year between 2019 and 2020 (Fig. 3 and Table 2). During the sampling, water samples were taken from the two depths, namely, the surface and the bottom, with the Niskin bottles. Primarily, water quality parameters $(\mathrm{pH}$, dissolved oxygen, turbidity, salinity, temperature, secchi depth) were measured during fieldwork. $\mathrm{pH}$, dissolved oxygen, salinity, temperature were measured using the multiparameter device (YSI Professional Plus Multiparameter Instrument). Turbidity was measured using the 2100P turbidimeter HACH device. To analyze the total suspended solids, estuary water was filtered from preweighed $\mathrm{GF} / \mathrm{F}$ filter papers which were previously dried at $105^{\circ} \mathrm{C}$. After filtering, the filter papers were dried again at $105^{\circ} \mathrm{C}$ and then weighed for calculation total suspended solids concentration (APHA, AWWA, WPCP 1980).

\section{Sample preparation and extraction}

Water samples ( $1 \mathrm{~L})$ was filtered through glass fiber filter papers (GF/F, $0.7 \mu \mathrm{m}$; Whatman, UK). Before the SPE extraction, liquid-liquid extraction was applied to the samples $(100 \mathrm{~mL}$ dichloromethane/chloroform (1/1, $\mathrm{v} / \mathrm{v})$ ). After extraction, the extracts were evaporated to dryness. Ultrapure water $(2 \mathrm{~mL})$ was added to the samples. Afterward, solid-phase extraction was performed. The SPE cartridges were conditioned with 4 $\mathrm{mL}$ of methanol and $4 \mathrm{~mL}$ of deionized water. Water sample $(2 \mathrm{~mL})$ was loaded to the cartridges. The loaded cartridges were rinsed with $2 \mathrm{~mL}$ of deionized water. The elution was performed with $4 \mathrm{~mL}$ of methanol and 4 $\mathrm{mL}$ of acidic methanol. The obtained eluents were evaporated to dryness then dissolved in $1 \mathrm{~mL}$ acetonitrile/water $(1 / 1, \mathrm{v} / \mathrm{v})$. All samples were stored at $20^{\circ} \mathrm{C}$ until HPLC analysis.

\section{Sampling sites}

Golden Horn Estuary was selected as a study area. The Golden Horn is $7 \mathrm{~km}$ long and 150-900 m wide (average $370 \mathrm{~m}$ ) with a surface area of about $2.5 \times 10^{6} \mathrm{~m}^{2}$ (DAMOC 1971; Fig. 3). The water depths decrease from about $40 \mathrm{~m}$ at the mouth to $2 \mathrm{~m}$ in the innermost estuary. However, some researchers are reported that the main freshwater source to the Golden Horn is only rainfall (Ersan et al. 2011; Gazioğlu et al., 2002; Sur et al. 2002, 2005; Zeki, 2012). Additionally, Bosphorus waters are input via creeks into the estuary from 2012 during remediation works (Istanbul Water and Sewerage Administration, ISKI). Bottom sediment scanning has been carried out continuously in the innermost region as well. 
Table 2. The locations of the sampling stations

$\begin{array}{ccc}\text { Stations } & \text { Latitudes }\left(^{\circ}\right)(\mathbf{N}) & \text { Longitudes }\left({ }^{\circ}\right)(\mathbf{E}) \\ \text { GB } & 41.0220 & 28.9742 \\ \text { UNK } & 41.0245 & 28.9648 \\ \text { KSP } & 41.0301 & 28.9562 \\ \text { CA } & 41.0323 & 28.9665 \\ \text { VB } & 41.0404 & 28.9487 \\ \text { HB } & 41.0447 & 28.9435 \\ \text { ES } & 41.0487 & 28.9402 \\ \text { BI } & 41.0530 & 28.9406 \\ \text { SB } & 41.0561 & 28.9444\end{array}$

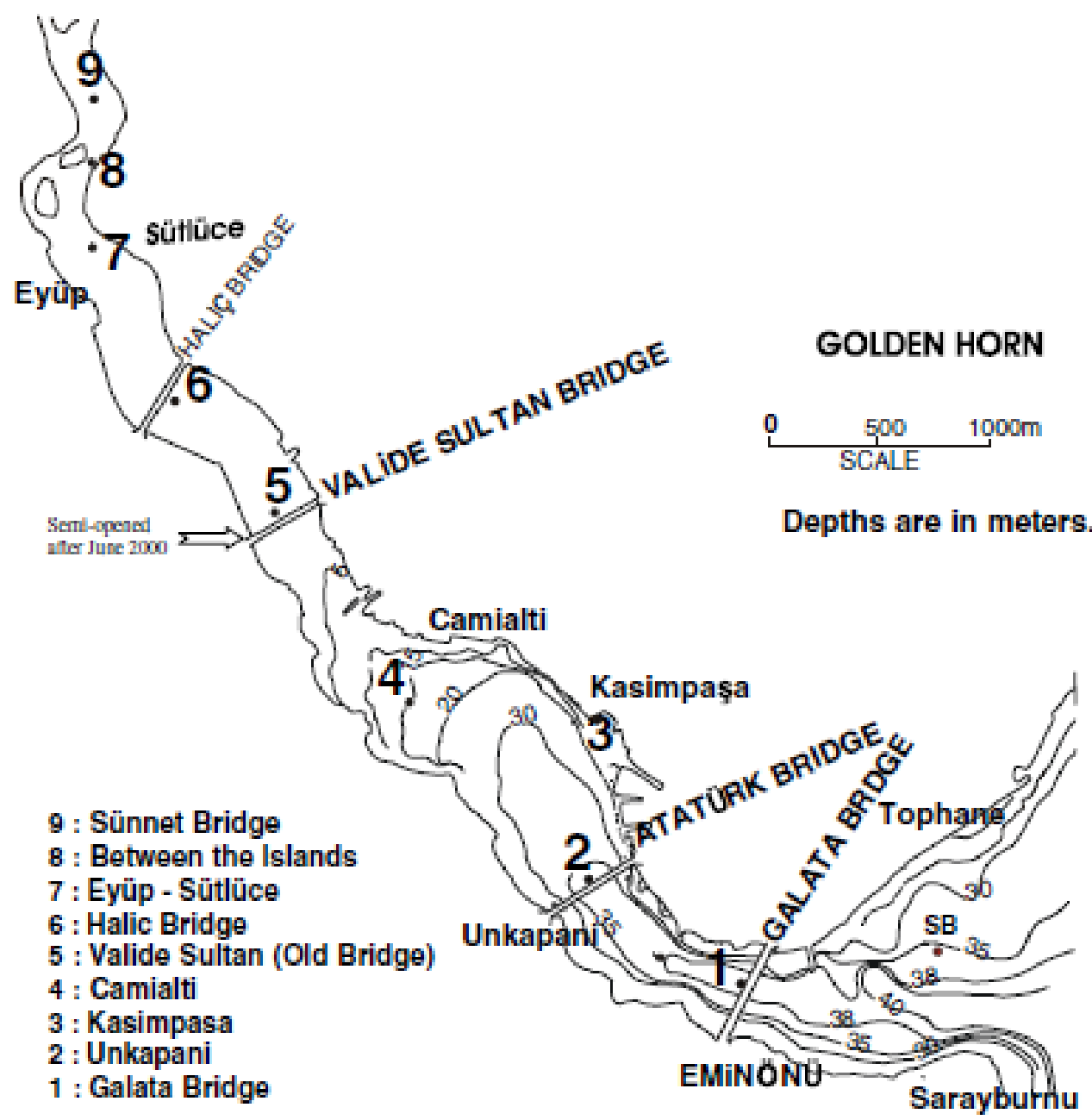

Fig.3. Locations of sample stations in the Golden Horn Estuary (Balkis et al. 2010).

\section{Instrumental analysis}

Chromatographic analyses were performed using a HPLC 1100 Series Instrument (Agilent, USA) with diode array detector (DAD) connected online. C-18 (250 $\times 4.6 \mathrm{~mm}$ i.d., $5 \mu \mathrm{m}$ thickness) column was used. Results were separated by gradient elution with acetonitrile (A) and a $25 \mathrm{mM}$ potassium dihydrogen phosphate solution (B) at $1.2 \mathrm{~mL} / \mathrm{min}$ flow rate. The gradient elution program was: $5-18.5 \% \mathrm{~A}$ in 13 mins, $18.5-50 \% \mathrm{~A}$ in 37 mins, 50-55\% $\mathrm{A}$ in 2 mins held for 5 mins, back to 5\% B in 10 mins held for 10 mins. The compounds were measured by the DAD detector and detected as $220 \mathrm{~nm}$. The analysis was completed in $60 \mathrm{~min}$. Method detection limits (MDL) and method quantification limits (MQL) for estrone, 17 $\beta$-estradiol and $17 \alpha$ - ethynylestradiol, were measured $(0.048-0.158 \mu \mathrm{g} / \mathrm{L}) ;(0.031-0.103 \mu \mathrm{g} / \mathrm{L})$; $(0.011-0.036 \mu \mathrm{g} / \mathrm{L})$ in water, respectively. Recovery $(\%)$ of estrone, $17 \beta$-estradiol and $17 \alpha$ - ethynylestradiol were $92,100,100$ respectively in this study.

\section{Results}

Surface and bottom water samples were examined in terms of the presence, distribution and concentration levels of hormones. Also, the water quality parameters (pH, salinity, turbidity, total suspended solids (TDS)) were measured seasonally (Table $3 \mathrm{a}, \mathrm{b}$ ). 
Table 3a. Seasonal variation of water quality parameters in surface water of the Golden Horn Estuary (Sea of Marmara, Turkey) in 2019-2020.

\begin{tabular}{|ccccc|} 
Seasons & $\mathbf{p H}$ & $\begin{array}{c}\text { Salinity } \\
\mathbf{( \% )}\end{array}$ & Turbidity (NTU) & $\begin{array}{c}\text { TSD } \\
(\mathbf{m g} / \mathbf{L})\end{array}$ \\
\hline Spring & $8.28-8.59$ & $14.48-18$ & $1.94-18.6$ & $8-19.8$ \\
\hline Summer & $7.85-8.37$ & $11.39-18.65$ & $1.68-9.7$ & $9.3-12.4$ \\
\hline Autumn & $8.03-8.4$ & $7.4-18.5$ & $1.8-15.6$ & $10-19.5$ \\
Winter & $7.39-7.79$ & $6.78-19.57$ & $1.9-12.5$ & $7.3-14.1$ \\
\hline
\end{tabular}

Table 3b. Seasonal variation of water quality parameters in bottom water of the Golden Horn Estuary (Sea of Marmara, Turkey) in 2019-2020.

\begin{tabular}{ccccc} 
Seasons & $\mathbf{p H}$ & $\begin{array}{c}\text { Salinity } \\
\mathbf{( \% )}\end{array}$ & Turbidity (NTU) & $\begin{array}{c}\text { TSD } \\
(\mathbf{m g} / \mathbf{L})\end{array}$ \\
\hline Spring & $8.27-8.75$ & $15.42-32.72$ & $1.8-47.8$ & $7.6-20.2$ \\
Summer & $7.86-8.36$ & $12.21-32.3$ & $1.83-9$ & $9.6-20.9$ \\
Autumn & $7.98-8.5$ & $7.51-31.8$ & $1.8-7$ & $9.2-19.5$ \\
Winter & $7.25-7.74$ & $8.38-32.8$ & $1.96-15.7$ & $8.5-24.6$
\end{tabular}

Terrestrial inputs have been flowed to the Golden Horn due to precipitation in winter. This situation has led to a decrease in $\mathrm{pH}$ and salinity.

\section{Surface water}

According to obtained data, the concentration of estrone was the range of $<0.048-1.069 \mu \mathrm{g} / \mathrm{L}$ and the average concentration was found as $0.352 \pm 0.1 \mu \mathrm{g} / \mathrm{L}$ in surface water of the Golden Horn Estuary. The highest concentration of estrone was detected as $1.069 \mu \mathrm{g} / \mathrm{L}$ at ES station, in summer season. Moreover, the concentration of estrone in autumn season, was found higher than the other seasons. Secondly, the high values in winter were also measured in both the middle and inner regions. It was found that the concentration levels of estrone were almost similar for all stations (Fig.4).

The concentration of $17 \beta$ - estradiol was the range of $<0.103-0.71 \mu \mathrm{g} / \mathrm{L}$ and the average concentration was found as $0.232 \pm 0.09 \mu \mathrm{g} / \mathrm{L}$ in surface water. The highest $17 \beta$ - estradiol concentration was measured as $0.71 \mu \mathrm{g} / \mathrm{L}$ at HB station in autumn. The concentration of this hormone in spring was found higher than the other seasons. It was determined that the intensity of the $17 \beta$ estradiol was higher at the GB, UNK and HB stations which are located in the external and middle region of Golden Horn Estuary, respectively (Fig.4).

For $17 \alpha$ - ethynylestradiol, the concentration was the range of $<0.011-1.49 \mu \mathrm{g} / \mathrm{L}$ in the Golden Horn Estuary. The average concentration was calculated as $0.376 \pm$ $0.08 \mu \mathrm{g} / \mathrm{L}$. The highest concentration of this hormone was $1.49 \mu \mathrm{g} / \mathrm{L}$ at the UNK station, in winter. The results also showed that the concentration of $17 \alpha-$ ethynylestradiol in winter season was higher than the other seasons. According to concentration levels, a homogeneous distribution was observed in all stations. (Fig. 4).

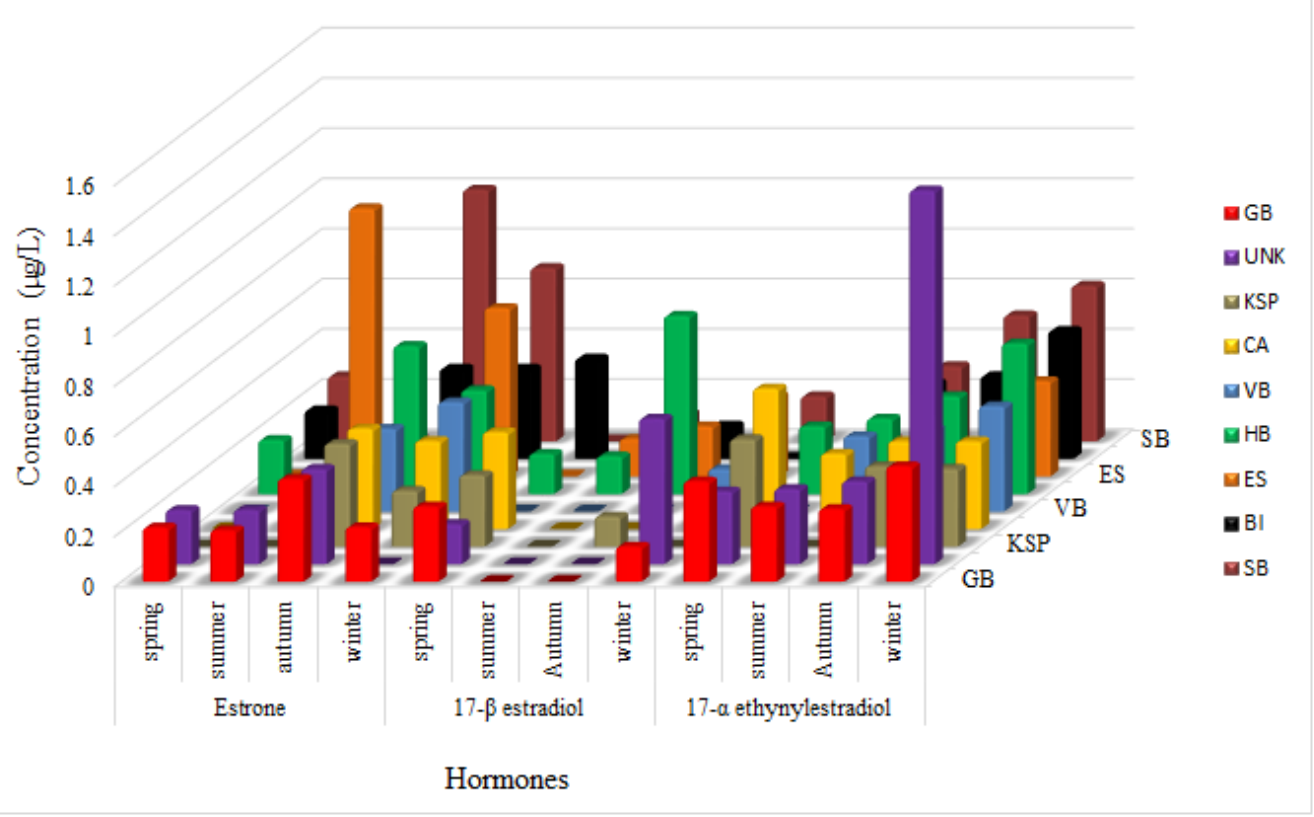

Fig. 4. Total concentrations of steroidal estrogens in surface water samples of Golden Horn during sampling periods. GB, Galata Bridge; UNK, Unkapanı; KSP, Kasımpasa; CA, Camialtı; VB, Valide Sultan Bridge; HB, Halic Bridge; ES, Eyüp-Sütlüce; BI; Between Islands; SB, Sünnet Bridge. 
According to the general distribution of natural and synthetic hormones in the surface water, it was found that the concentration of $17 \alpha$ - ethynylestradiol was higher than the other hormones. The highest value was observed in winter and measured as $1.49 \mu \mathrm{g} / \mathrm{L}$ at the UNK station. Besides, the concentration values of these three hormones showed an increasing distribution from the outer part of the Golden Horn Estuary to the inner part (GB-SB) (Fig. 4).

\section{Bottom water}

The concentration of estrone was ranged from $<0.048$ $0.81 \mu \mathrm{g} / \mathrm{L}$ and the average value was calculated as 0.336 $\pm 0.11 \mu \mathrm{g} / \mathrm{L}$ in bottom water. The highest concentration was determined as $0.81 \mu \mathrm{g} / \mathrm{L}$ at the SB station in winter season. The concentrations of estrone in bottom water, were higher in autumn and winter seasons than spring and summer seasons. Moreover, the intensity of the estrone was higher at the UNK, HB and SB stations which are located in the external, middle and internal regions of Golden Horn Estuary, respectively (Fig.5).

The concentration of $17 \beta$ - estradiol in bottom water was found in the range of $<0.103-5.25 \mu \mathrm{g} / \mathrm{L}$. The average value was $0.196 \pm 0.05 \mu \mathrm{g} / \mathrm{L}$. The highest concentration of $17 \beta$ - estradiol was $5.25 \mu \mathrm{g} / \mathrm{L}$ at the SB station in winter season. It showed that the value of $17 \beta$ - estradiol in winter was higher than the other seasons (Fig.5).

The concentration of $17 \alpha$ - ethynylestradiol was the range of $<0.011-1.65 \mu \mathrm{g} / \mathrm{L}$ and average concentration was $0.335 \pm 0.09 \mu \mathrm{g} / \mathrm{L}$. The highest concentration of $17 \alpha-$ ethynylestradiol in bottom water was measured as 1.65 $\mu \mathrm{g} / \mathrm{L}$ at the SB station in winter. Also, a homogeneous distribution was observed in concentration levels of $17 \alpha$ ethynylestradiol during all seasons (Fig.5). It was found that the concentration of $17 \alpha$ - ethynylestradiol was higher at the SB station than the other stations (Fig. 5) and the highest concentration was measured as 1.65 $\mu \mathrm{g} / \mathrm{L}$ in winter season (Fig. 5).

The results showed that the presence and concentration of steroidal hormones in bottom water were higher than the surface water. The general distribution of hormones in terms of concentration levels can be shown as $17 \alpha-$ ethynylestradiol> estrone> $17 \beta$ - estradiol in surface and bottom water of the Golden Horn Estuary (Fig. 4 and 5).

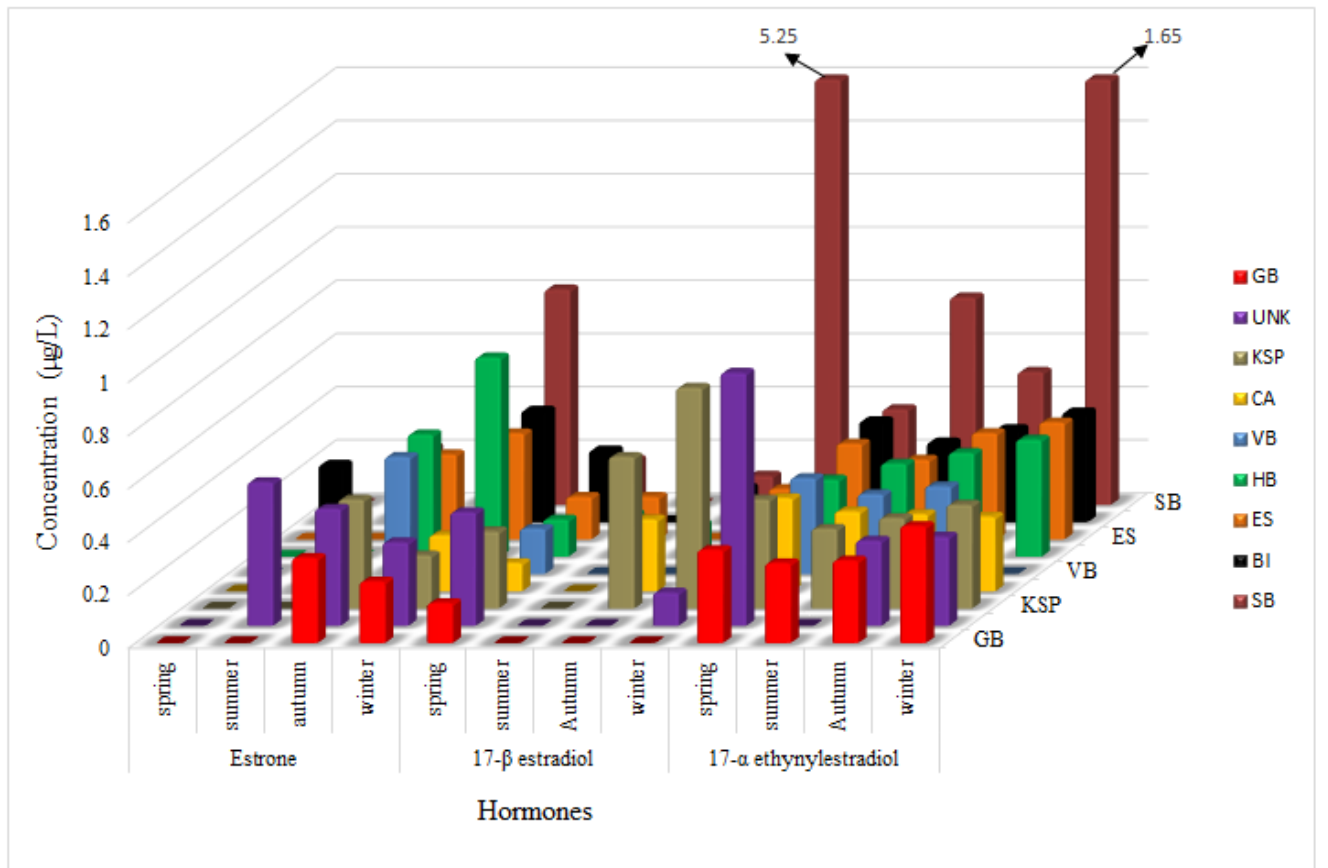

Fig. 5. Total concentrations of steroidal estrogens in bottom water samples of Golden Horn during sampling periods. GB, Galata Bridge; UNK, Unkapanı; KSP, Kasımpasa; CA, Camialt1; VB, Valide Sultan Bridge; HB, Halic Bridge; ES, Eyüp-Sütlüce; BI; Between Islands; SB, Sünnet Bridge.

\section{Discussion and Conclusion}

The existence, distribution and concentration of estrone, $17-\beta$ estradiol, $17-\alpha$ ethynylestradiol in the surface and bottom water of the Golden Horn Estuary (Sea of Marmara, Turkey) were examined on a yearly basis. Sampling were performed seasonally (on April 2019, June 2019, October 2019, January 2020). The results showed that the highest concentration in surface water belonged to 17- $\alpha$ ethynylestradiol. This concentration of $17-\alpha$ ethynylestradiol was measured as $1.49 \mu \mathrm{g} / \mathrm{L}$ at $\mathrm{UNK}$ station in winter season (Fig.4). For the bottom water, the highest concentration belonged to $17-\beta$ estradiol. This value was measured as $5.25 \mu \mathrm{g} / \mathrm{L}$ at $\mathrm{SB}$ station in winter season. Secondly, 17- $\alpha$ ethynylestradiol was determined and measured as $1.65 \mu \mathrm{g} / \mathrm{L}$ at the same station (Fig.5). Previous studies indicated that the high hormone concentration levels in winter came up due to the increase in wastewater input based on rainfalls and the suppression of bacterial activities at low 
temperatures (Kim and Carlson, 2007; Yang et al., 2011a,b; Yan et al., 2013). A variety of factors such as the flow rate of input surface water (stream, lake, etc.), switching to sediment or particulate matter, biodegradation, photodegradation and wastewater treatment processes might affect the pharmaceutical concentration in surface waters (Lindholm-Lehto et al., 2016; Moreno-González et al., 2014). Some of these processes such as photodegradation or biodegradation depend on environmental factors (temperature, sunlight and nutrient) (Lindholm-Lehto et al. 2016). Therefore, seasonal variations cause changes in the concentration of pharmaceuticals in surface waters and environmental transport (Paíga et al. 2016).

In winter season, the concentration of estrone was found at high levels in the surface and bottom waters at all stations in Golden Horn Estuary. Also, the concentrations of 17- $\beta$ estradiol and 17- $\alpha$ ethynylestradiol in bottom waters were high (Fig. 4 and 5). According to Turkish State Meteorological Service data, intensive rain transitions were seen in this region for one week before the sampling time (14.01.2020) (https://www.mgm.gov.tr). These transitions led to uncontrolled anthropogenic terrestrial inputs around the Golden Horn Estuary. High hormone levels suggest that terrestrial inputs carried by rain might carry micropollutants. Furthermore, the significant changes in the water quality parameters [especially $\mathrm{pH}$ (7.39-7.79), secchi depth (0.4-4 m) and salinity (6.78$19.57 \%$ ) decrease in surface water] were observed in winter months (Table 3a). This case supports that the terrestrial input reaches to the receiving environment in winter. The distribution and concentration of these three hormones were examined in surface and bottom water and observed an increasing distribution from the outer to inner part (GB-SB) of Golden Horn (Fig. 4 and 5).
Balkis et al. (2010) reported that the total suspended solids values are higher especially in the inner part of the Golden Horn (ES-SB). Streams, precipitation and terrestrial inputs through the biological activities are responsible for controlling the distribution in the inner regions. In this study, the highest value of total suspended solid $(24.6 \mathrm{mg} / \mathrm{L})$ was determined in bottom water at the Sünnet Bridge, in winter season. Similarly, Balkis et al. (2010) reported the highest total suspended solids in the bottom water at Sünnet Bridge station. The high level of total suspended solids indicated that the intense organic, terrestrial and human-induced burdens (micropollutants; hormones) originating from streams and precipitation accumulates in the inner region of the Golden Horn.

Consequently, the determination of the high concentration of total suspended solids in the bottom water of the Sünnet Bridge support to find higher concentrations of estrone, 17 $\beta$ - estradiol, 17 $\alpha$ ethynylestradiol $(0.81,5.25,1.65 \mu \mathrm{g} / \mathrm{L}$, respectively) at this station. Also, the high concentration of $17 \beta$ estradiol $(5.25 \mu \mathrm{g} / \mathrm{L})$ in bottom water at SB station indicates extremely conditions (such as heavy precipitation, uncontrolled terrestrial inputs) (Fig. 5).

The estrone concentration is usually found higher than $17 \beta$ - estradiol concentration in wastewater treatment plants (Chang et al., 2011; Jin et al., 2008). 17 $\beta$ estradiol can easily be oxidized to estrone in the environment (Andersen et al., 2003). This case causes to find a high concentration of estrone hormone in the estuary (Shi et al., 2014).

In this study, the general distribution of natural and synthetic hormones in terms of concentration levels in the Golden Horn in surface and bottom water was determined as $17 \alpha$ - ethynylestradiol> estrone> $17 \beta$ estradiol (Fig. 4 and 5). Similar results were reported by Shi et al. (2014) (Table 4).

Table 4. Summary of estrogen concentrations in water in the World.

\begin{tabular}{|c|c|c|c|c|}
\hline Regions & Sample type & Estrone & $17 \beta$ - estradiol & $17 \alpha$ - ethynylestradiol \\
\hline $\begin{array}{l}\text { South-Eastern } \\
\text { Australia }\end{array}$ & $\begin{array}{l}\text { Tidal estuary } \\
\text { water }\end{array}$ & - & - & $<0.03-0.12 \mathrm{ng} / \mathrm{L}$ \\
\hline China & Estuary water & BLD (ng/L) & BLD-75.8 ng/L & BLD- $9.22 \mathrm{ng} / \mathrm{L}$ \\
\hline Northern France & Estuary water & $0.37-10 \mathrm{ng} / \mathrm{L}$ & BLQ & BLQ \\
\hline Malaysia & $\begin{array}{c}\text { Surface estuary } \\
\text { water }\end{array}$ & $\begin{array}{c}<0.56-1.95 \\
n g / L\end{array}$ & $\begin{array}{c}<5.28-31.43 \\
n g / L\end{array}$ & $<0.3-7.67 \mathrm{ng} / \mathrm{L}$ \\
\hline USA & Estuary water & $0.78-1.2 \mathrm{ng} / \mathrm{L}$ & $0.58-0.83 \mathrm{ng} / \mathrm{L}$ & $3.01-4.67 \mathrm{ng} / \mathrm{L}$ \\
\hline East China & Estuary water & $\mathrm{ND}-10.0 \mathrm{ng} / \mathrm{L}$ & ND & - \\
\hline $\begin{array}{c}\text { Büyükçekmece Watershed, } \\
\text { Turkey }\end{array}$ & Water & BLD -6.04(ng/L) & BLD-10.2(ng/L) & BLD-14(ng/L) \\
\hline This study & Estuary water & $<0.048-1.06 \mu \mathrm{g} / \mathrm{L}$ & $<0.031-5.25 \mu \mathrm{g} / \mathrm{L}$ & $<0.011-0.95 \mu \mathrm{g} / \mathrm{L}$ \\
\hline
\end{tabular}

BLD: below limit of detection, BLQ: below limit of quantification, $N D$ : not dedected.

Previous studies pointed out that the main source of steroidal hormones in the aquatic environment is the excretion of humans and animals (de Mes et al., 2005; Jobling et al., 2006). In this study, the seasonal distribution of $17 \alpha$ - ethynylestradiol in the surface and bottom water of Golden Horn Estuary was found higher than the other hormones (Fig. 4 and 5). 17 $\alpha$ ethynylestradiol is also known as birth control pills so these pills are mostly used by women. Therefore, pharmaceutical wastes might reach to the Golden Horn 
through uncontrolled discharges and precipitation. Also, previous studies support these results (Ying et al. 2003).

The results obtained in this study compared with the hormone values determined in estuarine, gulf and watershed waters around the world and the results are shown in Table 4. The concentrations of hormones detected in the Golden Horn Estuary (Turkey) were found quite high (Table 4). Estrone, 17 $\beta$ - estradiol and $17 \alpha$ - ethynylestradiol concentrations were determined as [BLD], [BLD-75.8], [BLD- 9.22] ng/L in China (Ashfaq et al., 2019); [0.37-10], [BLQ], [BLQ] ng/L in Northern France (Noppe et al., 2007); [<0.56-1.95], [<5.2831.43], [<0.3- 7.67] ng/L in Malaysia (Hanun Ismail et al., 2019); and [0.78-1.2], [0.58-0.83], [3.01-4.67] ng/L in America (Zuo et al., 2006) respectively. Also, the concentration of $17 \alpha$-ethynylestradiol was found as $[<0.03-0.12] \mathrm{ng} / \mathrm{L}$ in South-Eastern Australia (Ferguson et al., 2013). A limited number of studies are carried out in Turkey related to aquatic environments (lakes, seas and bays). Aydın and Taninli (2013) reported lower concentrations of hormones in Buyukcekmece Lake in Turkey compared this study (Table 4). The results obtained in this study point out that even though the bottom screening and improvement studies have been carried out to the Golden Horn, Istanbul regularly since 1994, still uncontrollable inputs have been reached the receiving environment.

The presence, distribution and concentration of natural and synthetic hormones were determined in the Golden Horn on a yearly basis. The following conclusions can be drawn from the obtained data.

- The highest concentrations for all hormones were determined in winter seasons.

- The highest concentrations of estrone, 17 $\beta$ estradiol, and $17 \alpha$ - ethynylestradiol were measured as $1.069 \mu \mathrm{g} / \mathrm{L}, 5.25 \mu \mathrm{g} / \mathrm{L}, 1.65 \mu \mathrm{g} / \mathrm{L}$ in the Golden Horn, respectively.

- The highest concentration in hormones belonged to 17- $\alpha$ ethynylestradiol and was measured as 5.25 $\mu \mathrm{g} / \mathrm{L}$ at Sünnet Bridge station.

- The concentrations of hormones are found higher in bottom waters than the surface water.

- The general distribution of hormones in terms of concentration levels in Golden Horn Estuary (Sea of Marmara,Turkey) was determined as $17 \alpha-$ ethynylestradiol> estrone> $17 \beta$ - estradiol.

\section{Acknowledgements}

This study was supported by Scientific Research Projects Coordination Unit of Istanbul University (Project No: 31466 and 33621). We also thank to Istanbul Metropolitan Municipality Environmental Protection and Control Department Marine Services Directorate for using their ships in this study.

\section{References}

Adeel, M., Song, X., Wang, Y., Francis, D., Yang, Y. (2017). Environmental impact of estrogens on human, animal and plant life: A critical review. Environment International, 99, 107-119.

Andersen, H., Siegrist, H., Halling-Sorensen, B., Ternes, T.A. (2003). Fate of estrogens in a municipal sewage treatment plant. Environmental Science \& Technology, 37, 4021-4026.

APHA, AWWA, WPCP. (1980). In A. E. Greenberg, R. R. Trussel, L. S. Clesceri, M. A. H. Franson (Eds.), Standard methods for the examination of water and wastewater. 16th ed. Washington, DC: APHA.

Ashfaqa, M., Sun, Q., Ma, C., Rashid, A., Li, Y., Mulla S., Yu, C. (2019). Occurrence, seasonal variation and risk evaluation of selected endocrine disrupting compounds and their transformation products in Jiulong river and estuary, China. Marine Pollution Bulletin, 14(5), 370-376.

Aydin, E., Talinli, I. (2013). Analysis, occurrence and fate of commonly used pharmaceuticals and hormones in the Buyukcekmece Watershed, Turkey. Chemosphere, 90(6), 2004-2012.

Balkis, N., Müftüoğlu, E., Aksu, A., Sur, H.I., Apak, R. (2010). The chemical oceanographic consequences of environmental restoration projects in the Golden Horn estuary (Marmara Sea, Turkey). Environmental Monitoring and Assessment, 164, 67-79.

Chang, H., Wan, Y., Wu, S., Fan, Z., Hu, J. (2011). Occurrence of androgens and progestogens in wastewater treatment plants and receiving river waters: comparison to estrogens. Water Research, 45, 732-740.

DAMOC Consortium. (1971). Master Plan and feasibility reports for water and sewerage for the Istanbul region. (Vol.III, Part.II).

De Mes, T., Zeeman, G., Lettinga, G. (2005). Occurrence and fate of estrone, 17b-estradiol and 17 a-ethynylestradiol in stps for domestic wastewater. Environmental Science and Biotechnology, 4(4), 275.

Ersan, M.S., Balkis, N., Muftuoglu, E., Aksu, A., Burak, S. (2011). Metal pollution in surface sediments of the Golden Horn Estuary (Marmara Sea, Turkey) after the remedial actions. Asian Journal Of Chemistry, 23, 3320-3324

Ferguson, E.M., Allinson M., Allinson, G., Swearer, S.E., Hassell, K.L. (2013). Fluctuations in natural and synthetic estrogen concentrations in a tidal estuary in south-eastern Australia. Water research, 47(4), 1604-1615.

Gazioğlu C, Gökaşan E, Algan O, Yücel, ZY, Tok B, Doğan E (2002) Morphologic features of the Marmara Sea from multibeam data. Mar Geol 190:397-420.

Gimiliani, G.T., Fontes, R.F.C., \& Abessa, D. (2016). Modeling the dispersion of endocrine disruptors in the Santos Estuarine System (Sao Paulo State, Brazil). Brazilian Journal of Oceanography, 64(1), 1-8.

Hanun Ismail, N.A., Wee, S.Y., Kamarulzaman, N.H., Aris, A.Z. (2019). Quantification of multi-classes of 
endocrine-disrupting compounds in estuarine water. Environmental Pollution, 24(9), 1019- 1028.

Hook, G.E.R. (1997). Environmental Health Perspectives: EHP, 105, 7-10.

Jin, S., Yang, F., Liao, T., Hui, Y., Xu, Y. (2008). Seasonal variations of estrogenic compounds and their estrogenicities in influent and effluent from a municipal sewage treatment plant in China. Environmental Toxicology and Chemistry, 27, 146153.

Jobling, S., Williams, R., Johnson, A., Taylor, A., GrossSorokin, M., Nolan, M., Tyler, C.R., van Aerle, R., Santos, E., Brighty, G. (2006). Predicted exposures to steroid estrogens in Uk rivers correlate with widespread sexual disruption in wild fish populations. Environmental Health Perspectives, 114, 32-39.

Kim, S.C., Carlson, K. (2007). Temporal and spatial trends in the occurrence of human and veterinary antibiotics in aqueous and river sediment matrices. Environmental Science of Technology, 41, 50-57.

Kolodziej, E.P., Sedlak, D.L. (2007). Rangeland grazing as a source of steroid hormones to surface waters. Environmental Science \& Technology, 41(10), 35143520 .

Lindholm-Lehto, P.C., Ahkola, H.S.J., Knuutinen, J.S., Herve, S.H. (2016). Widespread occurrence and seasonal variation of pharmaceuticals in surface waters and municipal wastewater treatment plants in central Finland. Environmental Science Pollution Research, 23, 7985-7997.

Moreno-González, R., Rodríguez-Mozaz, S., Gros, M., Pérez-Cánovas, E., Barceló, D., León, V.M. (2014). Input of pharmaceuticals through coastal surface watercourses into a Mediterranean lagoon (Mar Menor, SE Spain): sources and seasonal variations. Science of the Total Environment, 490, 59-72.

Mulroy, A. (2001). When the cure is the problem. Water Environment Technology, 13(2), 32-36.

Noppe, H., Verslycke, T., De Wulf, E., Verheyden, K., Monteyne, E., Van Caeter, P., Janssen, C.R., De brabander H.F. (2007). Occurrence of estrogens in the Scheldt estuary: A 2-year survey. Ecotoxicology and Environmental Safety, 66, 1-8.

Paíga, P., Santos, L.H.M.L.M., Ramos, S., Jorge, S., Silva, J.G., Delerue-Matos, C. (2016). Presence of pharmaceuticals in the Lis river (Portugal): Sources, fate and seasonal variation. Science of the Total Environment 573, 164-177.

Pal, A., Gin, K.Y., Lin, A.Y., Reinhard, M. (2010). Impacts of emerging organic contaminants on freshwater resources: review of recent occurrences, sources, fate and effects. Science of the Total Environment, 408, 6062-6069.

Puckowski, A., Mioduszewska, K., Łukaszewicz, P., Borecka, M., Caban, M., Maszkowska, J., Stepnowski, P. (2016). Bioaccumulation and analytics of pharmaceutical residues in the environment: A review. Journal of Pharmaceutical and Biomedical Analysis, 127, 232-255.

Roshan, N., Taghizadeh, M.M. (2019). What levels of estrogen hormones can be found in swimming pool water? Applied Water Science, 9, 132.
Sarkar, B., Mandal, S., Tsang, Y. F., Vithanage, M., Biswas, J. K., Yi, H., Ok, Y.S. (2019). Sustainable sludge management by removing emerging contaminants from urban wastewater using carbon nanotubes. In M. N. V. Prasad, P. J. de Campos Favas, M. Vithanage, \& S. V. Mohan (Eds.), Industrial and municipal sludge: Emerging concerns and scope for resource recovery, 553-571.

Shi, J., Liu, X., Chen, Q., Zhang, H. (2014). Spatial and seasonal distributions of estrogens and bisphenol A in the Yangtze River Estuary and the adjacent East China Sea. Chemosphere, 111, 336-343.

Sur H. İ., Okuş E., Güven K.C., Yüksek A., Altık H., Kıratlı N., Ünlü S., Taş S., Aslan-Yılmaz A., Yılmaz N., Övez S., Müftüoğlu A. E., Karhan Ü., Öz İ. Demirel N. (2004), Water Quality Monitoring, Annual Report. Submitted to: İstanbul Water and Sewerage Administration (ISKI). Istanbul University, Institute of Marine Sciences and Management, İstanbul.

Sur, H.I., Okuş, E., Sarıkaya, H.Z., Altıok, H., Eroğlu, V., Öztürk, I. (2002). Rehabilitation and water quality monitoring in the Golden Horn. Water Science and Technology, 46 (8), 29-36.

Ternes, T.A. (2001). Analytical methods for the determination of pharmaceuticals in aqueous environmental samples. Trends in Analytical Chemistry, 20(8), 419-434.

Turkish State Meteorological Service (1937). Information about the weekly weather and rainfall in Turkey. Retrieved 14 January 2020 from https://www.mgm.gov.tr/eng/forecast-5days.aspx

Xuan, R., Blassengale, A. A., Wang, Q. (2008) Degradation of Estrogenic Hormones in a Silt Loam Soil. Journal of Agricultural and Food Chemistry, 56 (19), 9152-9158.

Yan, C.X., Yang, Y., Zhou, J.L., Liu, M., Nie, M.H., Shi, H., et al. (2013). Antibiotics in the surface water of the Yangtze Estuary: occurrence, distribution and risk assessment. Environmental Pollution, 175, 2229.

Yang, J.F., Ying, G.G., Zhao, J.L., Tao, R., Sua, H.C., Liu, Y.S. (2011a). Spatial and seasonal distribution of selected antibiotics in surface waters of the Pearl Rivers, China. Journal of Environmental Science and Health B 46, 272-280.

Yang, Y., Fu, J.L., Peng, H., Hou, L.J., Liu, M., Zhou, J.L., (2011b). Occurrence and phase distribution of selected pharmaceuticals in the Yangtze Estuary and its coastal zone. Journal of Hazardous Materials, 190, 588-596.

Ying, G.G., Kookana, R.S., Dillon, P. (2003). Sorption and degradation of selected five endocrine disrupting chemicals in aquifer material. Water Research, 37, 3785-3791.

Zeki, S. (2012). Assessing microbial water quality by membrane filtration and quantitative polymerase chain reaction ( $q P C R$ ) methods at Golden Horn ( $\mathrm{PhD}$ thesis). Istanbul University, Istanbul, Turkey.

Zuo, Y., Zhang, K., Deng, Y., (2006) Occurrence and photochemical degradation of $17 \alpha$-ethinylestradiol in Acushnet River Estuary, Chemosphere, 63, 15831590. 